\title{
Abiotic alterations caused by forest fragmentation affect tree regeneration: a shade and drought tolerance gradient in the remnants of Coastal Maulino Forest
}

\author{
Alteraciones abióticas causadas por la fragmentación del bosque afectan la regeneración \\ arbórea: un gradiente de tolerancia a la sombra y la sequía en los remanentes del Bosque \\ Maulino Costero
}

\author{
PABLO C. GUERRERO ${ }^{1,2, *} \&$ RAMIRO O. BUSTAMANTE ${ }^{1,2}$ \\ ${ }^{1}$ Departamento de Ciencias Ecológicas, Facultad de Ciencias, Universidad de Chile, Casilla 653, Santiago, Chile \\ ${ }^{2}$ Instituto de Ecología y Biodiversidad, Chile \\ * Corresponding author: pablo.c.guerrero@gmail.com
}

\begin{abstract}
Plant regeneration is strongly determined by light and soil moisture differences between habitats; both variables are modified by large-scale forest fragmentation. Several studies have indicated this alteration as the mechanism involved in tropical forest community change. The effects of fragmentation may be much more severe in Mediterranean and deciduous forests, because plant species in these forests show a stress tolerance tradeoff between shade and drought. Our study was performed in the deciduous fragmented Coastal Maulino Forest: Reserva Nacional Los Queules (RNLQ) and surrounding small fragments. We hypothesised that Aristotelia chilensis (shade intolerant but drought tolerant) should increase its regeneration in small patches as a consequence of the change in habitat suitability (i.e. luminous and drier), while Cryptocarya alba (shade tolerant but drought intolerant) should have less regeneration in small fragments. We also expected that Nothofagus glauca and $N$. obliqua, which have shade and drought tolerances intermediate between $A$. chilensis and $C$. alba, should respond less to forest fragmentation. We used two estimations of plant regeneration: (i) seedling and sapling densities via field observations and (ii) seed germination and seedling establishment via a field-based experiment. Natural regeneration patterns of $C$. alba indicated a depressed regeneration within small forest fragments compared to RNLQ, although experimental germination, establishment and recruitment proportions did not vary between habitats. In contrast, A. chilensis regeneration was favored by forest fragmentation, with increased seedling and sapling densities and germination in small forest fragments. Both $N$. glauca and N. obliqua were less affected by forest fragmentation in their natural and experimental regeneration. This study highlights the relevance of studying changes in abiotic factors as a consequence of human activities, and considering safe sites (defined by regeneration niche attributes) for implementing conservation actions and ecological restoration.
\end{abstract}

Key words: ecological restoration, forest fragmentation, safe sites, seed germination, seedling establishment.

\section{RESUMEN}

La regeneración en plantas está determinada por las diferencias de luz y humedad del suelo entre hábitats, ambas variables son modificadas por la fragmentación de bosques a gran escala. Varios estudios consideran esas alteraciones como parte del mecanismo involucrado en el cambio comunitario en bosques tropicales. Sin embargo, en bosques mediterráneos y deciduos esa tendencia podría ser más severa, debido a que las plantas presentan un "trade off" entre la tolerancia a la sombra y a la sequía. Nuestro estudio fue realizado en el Bosque Maulino Costero: Reserva Nacional Los Queules (RNLQ) y fragmentos aledaños de bosque. Hipotetizamos que Aristotelia chilensis (sombra intolerante pero tolerante a la sequía) debería aumentar su regeneración en fragmentos pequeños de bosque, como consecuencia del cambio en la idoneidad del hábitat (i.e. más luminoso y seco), mientras que, Cryptocarya alba (sombra tolerante pero sequía intolerante) debería reducir su regeneración en fragmentos pequeños de bosque. Nosotros además esperamos que Nothofagus glauca y $N$. obliqua, ambas con tolerancias a la sombra y a la sequía intermedias entre A. chilensis y C. alba, 
deberían responder en menor medida a la fragmentación del bosque. En este estudio utilizamos dos evaluaciones: (i) la abundancia de plántulas y juveniles a través de observaciones de campo y (ii) la germinación y establecimiento de plántulas vía un experimento de campo. Los patrones de regeneración natural de $C$. alba indican una reducción en la regeneración dentro de los fragmentos pequeños de bosque comparado con la RNLQ, a pesar de que en el experimento de campo, la proporción de semillas germinadas, de plántulas establecidas y reclutadas no variaron entre hábitats. Por el contrario, la regeneración de $A$. chilensis y de $N$. glauca fueron favorecidas por la fragmentación del bosque, con un aumento en las densidades de plántulas y juveniles y de la proporción de semillas germinadas en los fragmentos pequeños de bosque. Por otro lado, la regeneración de $N$. obliqua es limitada en ambos hábitats, y la fragmentación del bosque no afectaría diferencialmente su germinación. Este estudio llama la atención sobre la relevancia de estudiar los cambios en los factores abióticos como consecuencias de actividades humanas, y de considerar los "sitios seguros" (definidos por los atributos del nicho regeneracional) en la implementación de acciones de conservación y de restauración ecológica.

Palabras clave: restauración ecológica, sitios seguros, germinación de semillas, establecimiento de plántulas.

\section{INTRODUCTION}

Seed germination and seedling establishment are critical stages during the life cycle of plants, being strongly dependent on the abiotic environment where plants occur (Harper 1977, Baskin \& Baskin 1998, Kitajima \& Fenner 2000). Although the microclimates experienced by seeds and seedlings are controlled by a hierarchy of factors (weather conditions and vegetation structure), canopy openness within forests controls the quantity, quality, spatial and temporal distribution of light, and to some extent soil moisture content (Jennings et al. 1999); therefore open habitats are drier than closed ones. In tropical forests, changes in canopy openness and soil moisture following large-scale perturbations (i.e. deforestation and fragmentation) affect seed germination and seedling establishment in native plants (Kapos 1989, Kapos et al. 1997, Bruna 1999). Moreover, the direction and magnitude of such effects are dependent on the regeneration niche of each plant species (i.e. abiotic requirements), which respond differently to abiotic suitability within habitat heterogeneity (Grubb 1977, Denslow 1987, Chen et al. 1992, Grubb et al. 1996, Bloor \& Grubb 2003). These abiotic alterations are fundamental aspects in the mechanism by which in small remnants of native tropical forest shade-intolerant, pioneer trees have higher recruitment relative to shadetolerant species (Benitez-Malvido 1998, Laurance et al. 1998, Restrepo \& Vargas 1999, Sizer \& Tanner 1999, Bruna 1999, 2002, 2003); thus differential responses may affect plant regeneration and eventually forest community structure (Laurance et al. 1998, Benitez-
Malvido 1998, Benitez-Malvido \& MartínezRamos 2003, Bruna 1999, 2002, 2003).

The extent to which plant species can tolerate moisture stress in closed habitats depends on the length of the growing season across ecosystems (Valladares \& Niinemets 2008). Tropical plant species are characterized by the independence between drought and shade tolerances, while species from deciduous and Mediterranean forests are considered sensitive to the interaction between moisture and light stress (Valladares \& Niinemets 2008, Markesteijn \& Poorter 2009). Sensitive species show an evolutionary tradeoff between shade and drought tolerance, in which shade tolerant species are drought intolerant and shade intolerant species are drought tolerant (Smith \& Huston 1989, Valladares \& Niinemets 2008). How non-tropical plant species with different stress tolerances respond to soil moisture and variation in canopy openness in large-scale fragmented habitats remains largely unstudied.

The Coastal Maulino Forest is a unique forest type restricted to central Chile $\left(35-36^{\circ}\right.$ $\mathrm{S})$; despite its relatively scarce coverage within the Mediterranean-temperate climate transition, it is one of most critical areas for biodiversity conservation in the global scale due to the concentration of endemic species, the potential for the discovery of new species, the presence of phylogenetically unique species and the extent of direct or indirect human threat (San Martín \& Donoso 1996, Bustamante \& Castor 1998, Saavedra \& Simonetti 2001, SmithRamírez 2004, Veloso et al. 2005, Brooks et al. 2006, Echeverría et al. 2006). Deforestation and forest fragmentation began with the arrival of European colonizers in the XVI-XVII 
century and was intensified in the XX century; changing the structure and composition of the original landscape into a matrix composed of Pinus radiata $\mathrm{D}$. Don surrounding a mosaic of native forest fragments (San Martín \& Donoso 1996, Bustamante \& Castor 1998, Estades \& Temple 1999, Echeverría et al. 2006). Although exhaustive abiotic characterisations within the Coastal Maulino Forest remnants have not been performed, increasing evidence shows that forest fragmentation is linked with micro-scale abiotic modifications in small fragments, which compared to the largest forest remnant are characterized by less soil moisture (Henríquez 2002) and increased canopy openness (AcostaJamett \& Simonetti 2004). Quantitative information of how human landscape modification affects abiotic parameters, concomitantly with species regeneration, is required in order to understand community dynamics and to direct conservation and management efforts (Dunson \& Travis 1991, Guerrero \& Bustamante 2007).

The purpose of this study was to assess regeneration patterns in native tree species in a stress (i.e. shade and drought) tolerance gradient in the fragmented Coastal Maulino Forest: Reserva Nacional Los Queules (RNLQ) and surrounding small fragments. We compared the largest native forest remnant and four small forest fragments. We studied the regeneration of two species with contrasting regeneration niches, Cryptocarya alba Looser (Lauraceae) (shade tolerant but drought intolerant) and Aristotelia chilensis (Mol.) Stuntz (Elaeocarpaceae) (shade intolerant but drought tolerant). We incorporated Nothofagus glauca (Phil.) Krasser and N. obliqua (Mirb.) Oerst (Nothofagaceae) into the analysis, because their shade and drought tolerances are intermediate between A. chilensis and C. alba. To determine the regeneration of trees we recorded periodically seedling and sapling densities, using an observational approach, and (ii) seed germination and seedling establishment, using a field experiment approach. The small forest fragments have a similar composition to RNLQ but with a dominance of A. chilensis, $N$. obliqua and $N$. glauca (Bustamante et al. 2005). This assertion concomitantly with the trade-off between shade and drought tolerances led us to hypothesised that $A$. chilensis (shade intolerant but drought tolerant) should increase its regeneration in small fragments as a consequence of the change in habitat suitability (i.e. luminous and drier), while C. alba (shade tolerant but drought intolerant) should have reduced regeneration in small fragments. We therefore expected that Nothofagus species (with intermediate shade and drought tolerances) should have intermediate responses to forest fragmentation.

\section{METHODS}

\section{Study system}

The Coastal Maulino Forest is located in the Coast Range of central Chile; it has a humid Mediterranean-type climate with oceanic influence (Luebert \& Pliscoff 2006). Precipitation is seasonal and is concentrated during winter, with annual precipitation varying between 1113$1327 \mathrm{~mm}$ (Luebert \& Pliscoff 2006). The floristic composition has a mixture of different biogeographic origins: (i) Neotropical elements such as C. alba and Peumus boldus Mol. (Monimiaceae); (ii) Australasian elements such as Nothofagus species, Jovellana punctata Ruiz \& Pav. (Scrophulariaceae) and Drimys winteri J.R. et G. Forster (Winteraceae); (iii) other endemic elements such as the endangered tree species Gomortega keule (Mol.) Baillon (Gomortegaceae) and Pitavia punctata Mol. (Rutaceae) (San Martín \& Donoso 1996, Villagrán \& Hinojosa 1997).

This study was conducted in two habitat types of the Coastal Maulino Forest; the first habitat is the largest existing remnant of Coastal Maulino Forest (over 600 ha) and comprises the Reserva Nacional Los Queules (RNLQ) $\left(35^{\circ} 58^{\prime} \mathrm{S}-72^{\circ} 42^{\prime} \mathrm{W}\right)$; the second is represented by four small privately owned fragments of native forest, remnants of the original Coastal Maulino Forest ranging from 2 to 6 ha in size, located $2 \mathrm{~km}$ apart and between 0.2 and $2 \mathrm{~km}$ from RNLQ (see Donoso et al. 2003). The sizes of these smaller fragments are the most common of the remaining native forest (Estades \& Temple 1999).

\section{The study species}

Aristotelia chilensis is a shade-intolerant pioneer tree, 3-4 $\mathrm{m}$ in height that frequently occurs in 
open and disturbed areas (Rodríguez et al. 1983). Flowering occurs from September to December (Hoffmann 1998). Fruits are berries with 2-3 seeds per fruit, dispersed by birds and foxes from December to February (Rodríguez et al. 1983); seed germination occurs from March to November (Valdivia \& Simonetti 2007). Cryptocarya alba is an endemic, shade-tolerant tree that lives in mesic habitats of central Chile (Armesto \& Martínez 1978). Flowering occurs during spring and summer (from October to January) (Hoffmann 1998). Fruits are red, oneseeded drupes which ripen between March and July and are dispersed by birds and foxes; seed germination and seedling establishment occur from September to December (Bustamante \& Simonetti 2000). Nothofagus obliqua and $N$. glauca are endemic to southern temperate forests (Rodríguez et al. 1983, Donoso 1997); flowering occurs in September and each fruit possess 3 nuts; in $N$. obliqua individual nuts are $\sim 8 \mathrm{~mm}$ long, while in $N$. glauca, $\sim 17 \mathrm{~mm}$ long. Dispersal occurs from March to the end of April, and germination occurs from July to September (Donoso 1975).

\section{Abiotic environment}

Soil moisture content was estimated using a gravimetric method; sampling 20 cups of 200 $\mathrm{cm}^{3}$ (each) from RNLQ and five per forest fragment. Samples were taken in each of the experimental units that had been selected for the germination and establishment assays (see below), hermetically sealed and transferred to the laboratory. The fresh weight of samples was recorded, and samples were then dried at $50{ }^{\circ} \mathrm{C}$ for 48 hours before being reweighed. Soil moisture was measured over a period of 12 months, from March 2002 to March 2003.

Canopy openness was assessed as an indirect estimation of light intensity within the forest, defined as the proportion of the area viewed from a single point not covered by the canopy of shrubs and trees. This estimate is regarded as an appropriate estimator of light availability for plants; higher values of canopy openness represent more light availability (Jennings et al. 1999). This parameter was estimated twice, in March 2003 and October 2003, by taking photographs using a digital camera (Canon Powershot G2), with a diagonal field of view of $\sim 53^{\circ}$ (for methodological details see Bunnell \& Vales 1990, Jennings et al. 1999). We chose March and October because in a previous study, in those months no differences in litter production were detected (Palacios-Bianchi 2002); their study also indicated that these differences are commonly result of storms. The camera was installed on a tripod with a spirit level to control the horizontal. One photo was taken in each of the experimental units utilized for the germination and establishment assays (see below). Photographic analyses were conducted using the software Scion Image 4.02 for Windows.

Differences in soil moisture and canopy openness were evaluated using a repeated measure analysis of variance (ANOVA), incorporating time (in months) as the repeated measure and habitat as a fixed factor. Also, to test whether soil moisture was modulated by canopy openness we performed a regression analysis between these variables in the RNLQ and small forest fragment data pooled. Proportion data were arcsine transformed to satisfy assumptions of normality (Zar 1999).

\section{Natural regeneration}

Sapling (height $>50 \mathrm{~cm}$; diameter at breast height $<10 \mathrm{~cm}$ ) densities were measured in March 2003 for the four tree species selected for this study, using 12 transects $(50 \times 1 \mathrm{~m} ; 50$ $\mathrm{m}$ apart) per habitat (three per fragment). All transects were located in the center of fragments. In addition, in each transect we simultaneously evaluated seedling (height $<50$ $\mathrm{cm})$ densities of each species, counting all seedlings within 12 plots $\left(1 \mathrm{~m}^{2}, 2 \mathrm{~m}\right.$ apart); thus we estimated the mean seedling densities per transect. Sapling transects and seedling plots were considered as experimental units. For each species we evaluated separately differences of their seedling and sapling densities between habitats using one-way ANOVAs with habitat as fixed factor. Seedling and sapling data were $\log (x+1)$ transformed to satisfy assumptions of normality (Zar 1999).

\section{Seed germination and seedling establishment}

Seed germination and seedling establishment were assessed for the four study species across habitats using a field experiment conducted twice (two cohorts) during consecutive periods, 
from June 2001 (at the beginning of winter) to March 2002 (at the end of summer), and subsequently from June 2002 to March 2003. For each period, we used 28 experimental units (replicates) per habitat, 28 in RNLQ and seven in each of the four small fragments). Each experimental unit included the four studied species; all were distributed in the interior (> $20 \mathrm{~m}$ from the edge) of the reserve and 15-20 m apart in the fragments. Thus we obtained a sample size of 56 replicates per year.

In each replicate, we buried four transparent circular plastic cups $(10 \mathrm{~cm}$ diameter $)$ with holes in the bottom to allow water drainage. We sowed 10 seeds within each cup (one cup per species) on the surface of the soil and covered the cup with leaf litter. The study species are abundant in seed traps of $0.5 \times 0.5$ $\mathrm{m}$, suggesting no dispersal limitations (Valdivia \& Simonetti 2007). Celis-Diez et al. (2004) documented similar $C$. alba seed densities in natural conditions. Seed predators (birds, foxes and rodents) were excluded from experimental units using circular wire mesh $(1 \mathrm{~m}$ diameter and 1 meter height). Seeds of all species were obtained from the Centro de Semillas Facultad de Ciencias Forestales (CESAF), Universidad de Chile (certified with $\geq 95 \%$ viability). A seed was considered as germinated when the cotyledons were visible without removing the litter. Germination proportion, $P(G)$, was defined as the total number of germinated seeds recorded between June and March divided by the total number of seeds (10) initially placed in a plastic cup. Seedling establishment proportion, $\mathrm{P}(\mathrm{E})$, was defined as the total number of seedlings that survived to the end of each experiment (i.e. March) divided by the total number of germinated seeds. To calculate recruitment proportion $\mathrm{P}(\mathrm{R})$, the proportion of germinated seeds was multiplied by the proportion of established seedlings.

We evaluated separately for each species $\mathrm{P}(\mathrm{G})$ differences between habitats and years using two-way ANOVAs, with species and years as fixed factors. Also, we used a one-way ANOVA to compare $\mathrm{P}(\mathrm{E})$ between habitats, considering it as a fixed factor. Establishment differences between species were not evaluated because only $C$. alba achieved seedling establishment. Proportions were arcsine transformed to satisfy assumptions of normality (Zar 1999).

\section{RESULTS}

\section{Soil moisture and canopy openness}

Soil moisture was significantly greater in RNLQ than in small forest fragments (repeated measure ANOVA, $\mathrm{F}_{1,38}=22.03 ; \mathrm{P}<0.0001$ ). In addition, soil moisture varied strongly over time (months) (repeated measure ANOVA, $\left.\mathrm{F}_{11,418}=19.16 ; \mathrm{P}<0.0001\right)$; soil moisture was minimal in March 2003 and was greater during the autumn - winter interphase (May and June), spring and early summer (October, November and December) (Fig. 1). The interaction between habitat and months was not significant (repeated measure ANOVA, $\mathrm{F}_{11,418}=1.69 ; \mathrm{P}=$ 0.072).

Small forest fragments have more canopy openness than RNLQ (repeated measure ANOVA, $\left.\mathrm{F}_{1,54}=16.06 ; \mathrm{P}<0.001\right)$; also in March canopy openness was greater than in October (repeated measure ANOVA, $\mathrm{F}_{1,54}=$ 92.20; $\mathrm{P}<0.001$; Table 1). Interaction between habitat and time was significant (repeated measure ANOVA, $\left.\mathrm{F}_{1,54}=7.30 ; \mathrm{P}=0.009\right)$, indicating that canopy openness between habitats varied differently with months. In fact, in small forest fragments the reduction of canopy openness between March and October was greater than the reduction observed in RNLQ (Table 1). In addition, the regression between soil moisture and canopy openness was negative (slope $=-0.019 ; \mathrm{r}^{2}=0.175, \mathrm{~F}_{1,38}=$ 8.04; $\mathrm{P}=0.007)$, but the low coefficient of determination suggests that the two parameters are weakly associated.

TABLE 1

Canopy openness of the Reserva Nacional Los Queules and small forest fragments in two different months (March and October).

Apertura de dosel de la Reserva Nacional Los Queules y fragmentos pequeños de bosque en dos meses diferentes (marzo y octubre).

\begin{tabular}{lcc}
\hline & $\begin{array}{c}\text { March } \\
(\text { Mean } \pm \text { S.E. })\end{array}$ & $\begin{array}{c}\text { October } \\
(\text { Mean } \pm \text { S.E. })\end{array}$ \\
\hline $\begin{array}{l}\text { Reserva Nacional } \\
\text { Los Queules }\end{array}$ & $17.71 \pm 1.08$ & $12.17 \pm 1.12$ \\
Small forest fragments & $30.40 \pm 2.78$ & $18.31 \pm 1.98$
\end{tabular}


Seedling and sapling densities

Only $C$. alba presented seedlings in both habitats, 10 times greater in RNLQ compared to forest fragments (one-way ANOVA, $\mathrm{F}_{1,22}=$ 40.36; $\mathrm{P}<0.0001 ;$ Table 2). In contrast, seedlings of $A$. chilensis and $N$. glauca only occurred in small forest fragments and were absent in RNLQ (Table 2). We did not find seedlings of $N$. obliqua in either of the habitats (Table 2).

Saplings of A. chilensis, C. alba and $N$. glauca were present in both RNLQ and small forest fragments, while $N$. obliqua was absent in RNLQ (Table 2). Aristotelia chilensis had significantly greater sapling densities in forest fragments than in RNLQ (one-way ANOVA, $\mathrm{F}_{1,22}=10.26 ; \mathrm{P}=0.004 ;$ Table 2), whereas the sapling density of $C$. alba was significantly greater in RNLQ than in small forest fragments (one-way ANOVA, $\mathrm{F}_{1,22}=8.08 ; \mathrm{P}=0.009$; Table 2).
Germination, establishment and recruitment proportions

Aristotelia chilensis and N. glauca had better germination in small forest fragments compared to RNLQ (two-way ANOVAs, A. chilensis: $\mathrm{F}_{1,108}=7.17 ; \mathrm{P}=0.009 ;$ N. glauca : $\mathrm{F}_{1,108}=6.56 ; \mathrm{P}=0.012 ;$ Table 3$)$, more germinating during 2002-2003 than in 20012002 (two-way ANOVAs, A. chilensis: $\mathrm{F}_{1,108}=$ 65.60; $\mathrm{P}<0.001 ;$ N. glauca: $\mathrm{F}_{1,108}=4.78 ; \mathrm{P}=$ 0.031; Table 3). Cryptocarya alba and $N$. obliqua germinated in the same proportion in RNLQ and in small forest fragments (two-way ANOVAs, $C$. alba: $\mathrm{F}_{1,108}=0.03 ; \mathrm{P}=0.865 ; N$. obliqua: $\mathrm{F}_{1,108}=0.07 ; \mathrm{P}=0.794 ;$ Table 3 ), and had greater germination during 2001-2002 than 2002-2003 (two-way ANOVAs, C. alba: $\mathrm{F}_{1,108}$ $=26.77 ; \mathrm{P}<0.001 ;$ N. obliqua: $\mathrm{F}_{1,108}=35.08$; $\mathrm{P}<0.001$; Table 3). The interaction between habitat and year was not significant in any of the species (two-way ANOVAs, A. chilensis:

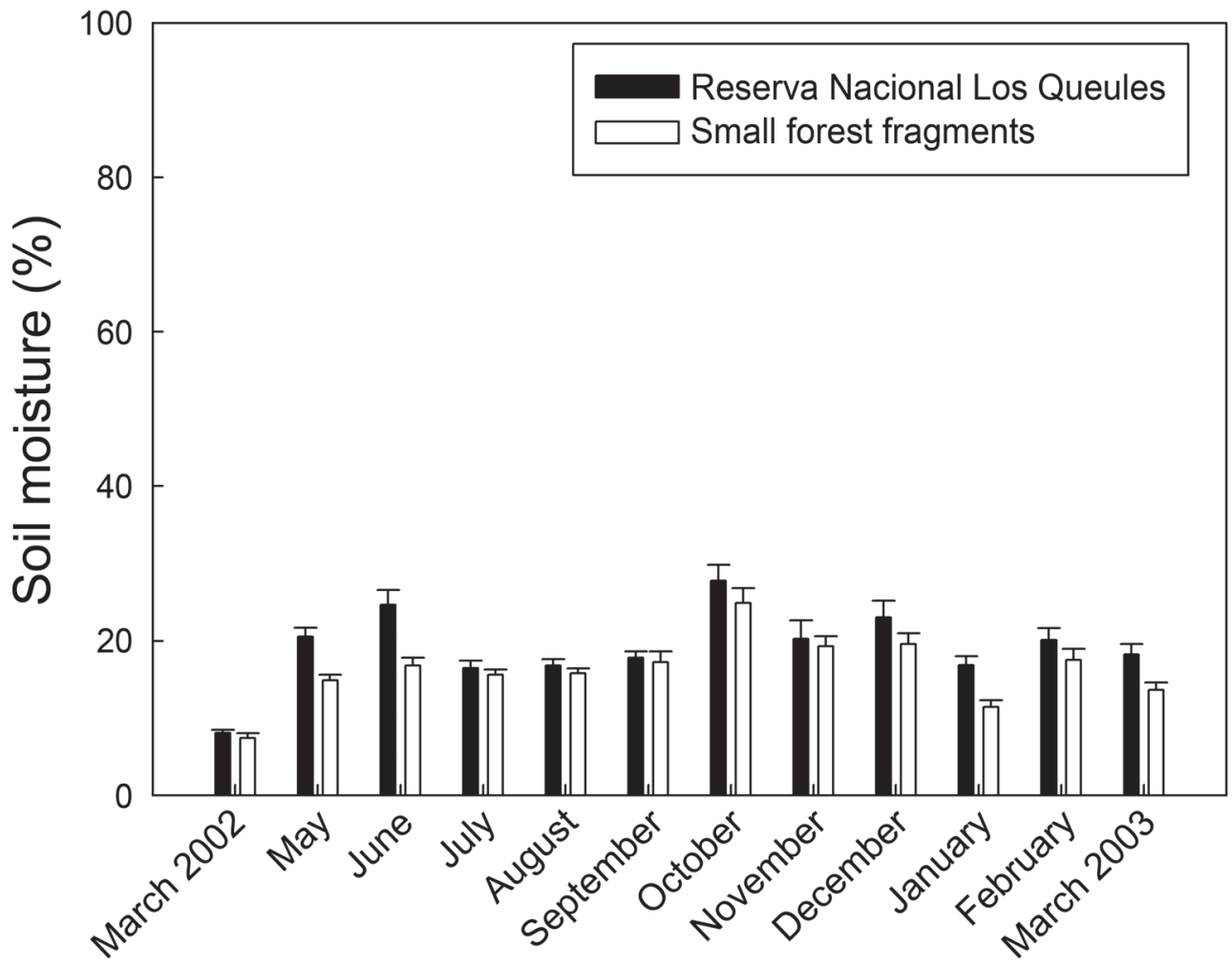

Fig. 1: Soil moisture content in the Reserva Nacional Los Queules and small forest fragments. Vertical lines represent means \pm SE.

Contenido de humedad del suelo en la Reserva Nacional Los Queules y fragmentos pequeños de bosque. Líneas verticales representan medias $\pm \mathrm{EE}$. 
$\mathrm{F}_{1,108}=2.65 ; \mathrm{P}=0.106 ;$ C. alba: $\mathrm{F}_{1,108}=0.37$ $\mathrm{P}=0.543 ;$ N. glauca $: \mathrm{F}_{1,108}=1.12 ; \mathrm{P}=0.293 ;$ N. obliqua: $\mathrm{F}_{1,108}=0.17 ; \mathrm{P}=0.680$; Table 3 )

Seedling establishment was low and was observed exclusively for $C$. alba; it was not statistically different between habitats (oneway ANOVA, $\mathrm{F}_{1,108}=0.98 ; \mathrm{P}=0.320$; Table $3)$. However, a higher seedling establishment was detected during 2002-2003 than during 2001-2002 (one-way ANOVA, $\mathrm{F}_{1,108}=20.13 ; \mathrm{P}$ $<0.001$; Table 3).

\section{TABLE 2}

Seedling and sapling densities of Aristotelia chilensis, Cryptocarya alba, Nothofagus glauca and N. obliqua within the Reserva Nacional

Los Queules and small forest fragments.

Densidades de plántulas y juveniles de A. chilensis, $C$. alba, $N$. glauca y $N$. obliqua dentro de la Reserva Nacional Los Queules y fragmentos pequeños de bosque.

\begin{tabular}{cc}
\hline $\begin{array}{c}\text { Reserva Nacional } \\
\text { Los Queules } \\
(\text { Mean } \pm \text { S.E. })\end{array}$ & $\begin{array}{c}\text { Small forest } \\
\text { fragments } \\
(\text { Mean } \pm \text { S.E. })\end{array}$ \\
\hline
\end{tabular}

Seedlings densities (seedlings $\mathrm{m}^{-1}$ )

$\begin{array}{lcc}\text { A. chilensis } & 0 & 3.42 \pm 0.83 \\ \text { C. alba } & 155.08 \pm 33.09 \text { a } & 15.58 \pm 3.70^{\mathrm{b}} \\ N . \text { glauca } & 0 & 0.58 \pm 0.33 \\ N . \text { obliqua } & 0 & 0\end{array}$

Sapling densities (saplings $\mathrm{m}^{-1}$ )

\begin{tabular}{lcc} 
A. chilensis & $0.05 \pm 0.01^{\mathrm{a}}$ & $0.12 \pm 0.01^{\mathrm{b}}$ \\
C. alba & $0.15 \pm 0.04^{\mathrm{a}}$ & $0.03 \pm 0.01^{\mathrm{b}}$ \\
$N$. glauca $^{\text {N. obliqua }}$ & $0.01 \pm 0.01$ & $0.03 \pm 0.02$ \\
\hline
\end{tabular}

Different letters indicate significant differences $(P<0.05)$. No statistical analyses were performed when no seedlings or saplings were recorded in one of the two habitats.

\section{DISCUSSION}

Global effects of forest fragmentation around the world are still not fully understood; most studies have been concentrated in tropical forests where species showed drought and shade tolerance independence. This study contributes with some relevant information which is currently lacking, and may have implications in the ecological restoration of the endangered Coastal Maulino Forest. We examined the relationship between the alterations of canopy openness and soil moisture of small forest fragments compared to the largest remnant of the Coastal Maulino Forest (RNLQ), and the regeneration of four tree species in a regeneration niche gradient.

Micro-scale abiotic environmental descriptions showed, as expected, that soil moisture decreased and canopy openness increased in small forest fragments compared to RNLQ. Both variables varied over time (months), indicating that seasonality clearly influences soil moisture and canopy openness (leaf release of deciduous species). The interaction between habitats and time was not significant in the case of soil moisture, although canopy openness varied significantly; suggesting that forest fragmentation influences the micro-scale abiotic environment in distinct ways. Forest fragmentation is a "press-type" perturbation because species removal is maintained over time (Bender et al. 1984); its effects on the micro-scale abiotic environment are complex as canopy openness and soil moisture differ in their responses to forest fragmentation. In fact, the alterations observed in soil moisture (consequence of forest fragmentation) were not maintained in time, and may affect forest community as a "pulsetype" disturbance. Although we evaluated canopy openness only in two months, our results suggest that alterations may be maintained over time and may affect the forest community as a press-type perturbation, in which canopy structure and its consequence affect light within small fragments of the Coastal Maulino Forest (Jennings et al. 1999). This disparity and the weak association between forest canopy openness and soil moisture may be a consequence of the increased litter accumulation during some months within small forest fragments, this can buffer soil moisture differences between habitats although canopy openness varied (Palacios-Bianchi 2002).

In our study, we obtained three regeneration patterns: 1. Depressed regeneration in small forest fragments in the shade tolerant C. alba, with lower seedling and sapling densities in small forest fragments compared to RNLQ, even though germination and establishment did not vary between small forest fragments and RNLQ. This reduction in $C$. alba regeneration was also reported by Bustamante et al. (2005), in which the seedling adult ${ }^{-1}$ ratio in RNLQ 
(8.5 seedlings adult ${ }^{-1}$ ) was greater than in small forest fragments (3.2 seedlings adult $\left.{ }^{-1}\right) .2$. Enhanced regeneration in small forest fragments in the shade intolerant A. chilensis and the intermediate shade intolerant $N$. glauca, which responded positively to forest fragmentation, increasing their seedling and sapling densities and seed germination in small forest fragments compared to RNLQ. Bustamante et al. (2005) detected seedlings of A. chilensis exclusively in small forest fragments although adults were not detected in any of these habitats. However, in the case of $N$. glauca, our results are not in agreement with those of Bustamante et al. (2005), because they only detected seedlings in RNLQ (0.6 seedlings adult $\left.^{-1}\right)$. One factor that may account for the difference between the studies is that $N$. glauca establishment may be constrained by seed limitations (Burgos et al. 2008). 3. Limited regeneration in both habitats. $N$. obliqua presented surprisingly low regeneration; only a few saplings were observed in small forest fragments. This limited regeneration is in agreement with Bustamante et al. (2005), although they found more regeneration in
RNLQ (0.3 seedling adult $\left.{ }^{-1}\right)$ than small forest fragments $\left(0.03\right.$ seedlings adult $\left.{ }^{-1}\right)$.

The germination and seedling establishment experiment showed differences among species; $N$. obliqua and C. alba presented no differences in their seed germination, as they germinated and established uniformly in both habitats, suggesting that in these early stages neither species was affected by canopy openness changes nor soil moisture differences between habitats. Although in the case of N. obliqua this could be partially explained by the low level of germination recorded, these results were particularly unexpected considering the drought- intolerance of $C$. alba, suggesting that this species may increase its requirements of humidity during ontogeny (i.e. seedling and saplings; Table 2). Granivory could also be significant in shaping regeneration patterns because in small forest fragments enhanced seed predation has been reported (Donoso et al. 2003). By contrast, A. chilensis and N. glauca increased their germination in small forest fragments compared to RNLQ, suggesting that these species are light limited in RNLQ. Burgos et al (2008) described no variation in $N$.

TABLE 3

Germination of Aristotelia chilensis, Cryptocarya alba, Nothofagus glauca and N. obliqua in the Reserva Nacional Los Queules and small forest fragments during two consecutive years. Establishment and recruitment proportions were available only for C. alba.

Germinación de A. chilensis, C. alba, N. glauca y N. obliqua en la Reserva Nacional Los Queules y fragmentos pequeños de bosque en dos años consecutivos. Las proporciones de plántulas establecidas y reclutadas fueron disponibles solo para C. alba.

\begin{tabular}{|c|c|c|c|c|}
\hline & \multicolumn{2}{|c|}{ 2001-2002 } & \multicolumn{2}{|c|}{$2002-2003$} \\
\hline & $\begin{array}{c}\text { Reserva Nacional } \\
\text { Los Queules } \\
\text { (Mean } \pm \text { S.E.) }\end{array}$ & $\begin{array}{c}\text { Small forest } \\
\text { fragments } \\
\text { (Mean } \pm \text { S.E.) }\end{array}$ & $\begin{array}{c}\text { Reserva Nacional } \\
\text { Los Queules } \\
\text { (Mean } \pm \text { S.E.) }\end{array}$ & $\begin{array}{c}\text { Small forest } \\
\text { fragments } \\
\text { (Mean } \pm \text { S.E.) }\end{array}$ \\
\hline \multicolumn{5}{|c|}{$P(G)=$ seed germination proportion } \\
\hline A. chilensis & $0.08 \pm 0.01^{\mathrm{a}}$ & $0.12 \pm 0.02^{b}$ & $0.30 \pm 0.03^{\mathrm{c}}$ & $0.49 \pm 0.04^{\mathrm{d}}$ \\
\hline C. alba & $0.59 \pm 0.04^{\mathrm{a}}$ & $0.63 \pm 0.04^{\mathrm{a}}$ & $0.30 \pm 0.04 \mathrm{~b}$ & $0.29 \pm 0.05 \mathrm{~b}$ \\
\hline N. glauca & $0.05 \pm 0.01^{\mathrm{a}}$ & $0.08 \pm 0.02 \mathrm{~b}$ & $0.07 \pm 0.01^{\mathrm{c}}$ & $0.15 \pm 0.02 \mathrm{~d}$ \\
\hline N. obliqua & $0.19 \pm 0.02^{a}$ & $0.20 \pm 0.02^{a}$ & $0.07 \pm 0.02^{b}$ & $0.05 \pm 0.01 b$ \\
\hline \multicolumn{5}{|c|}{$P(E)=$ seedling establishment proportion } \\
\hline C. alba & $0.01 \pm 0.01$ & 0 & $0.26 \pm 0.05$ & $0.16 \pm 0.04$ \\
\hline \multicolumn{5}{|c|}{ Recruitment proportion $P(R)=P(G) \times P(E)$} \\
\hline C. alba & 0 & 0 & $0.07 \pm 0.02$ & $0.06 \pm 0.01$ \\
\hline
\end{tabular}

Different letters indicate significant differences $(\mathrm{P}<0.05)$. 
glauca germination between habitats; we suspect that their result could be partially explained by the extremely low germination that year $(2 \%)$.

Cryptocarya alba establishment varied between years (Table 3 ), suggesting that climatic variation may also produce large variations in regeneration of species. During the first experiment (2001-2002) the nearest climatic station recorded more total precipitation (952 $\mathrm{mm})$ than in the second year (2002-2003) (837 $\mathrm{mm}$ ) (Dirección Meteorológica de Chile, unpublished information). However, during the course of the second experiment precipitation episodes were recorded in all months from June to January, contrary to the first experiment in which no rain was recorded in December and January. This suggests that the distribution of the rain within years may be more crucial than the total precipitation in a year (Bustamante in press). Indeed, the absence of experimental seedling establishment in A. chilensis, $N$. glauca and $N$. obliqua suggests that the demographic bottleneck in the early stages of the life cycle is a wide phenomenon affecting an array of species (Table 3). The magnitude of this demographic limitation suggests that shade and moisture stress might produce synergic effects, as soil drought and canopy closure become more severe simultaneously during summer, considered as the critical season in central Chile which produces massive mortality of woody seedlings (Fuentes et al. 1984, 1986). However, the increased seedling and/or sapling densities of $A$. chilensis, $N$. glauca and $N$. obliqua within small forest fragments compared to RNLQ (Table 2) suggests that one of these constraints is relaxed in some years. Soil moisture stress in summer might be relaxed in rainy years as observed during El Niño episodes, because they influence the occurrence of late spring rainfall, and therefore provide important water supply during the most stressing and critical months (Montecinos \& Aceituno 2003). How El Niño influences plant regeneration has been largely studied in arid and semi-arid ecosystems (Holmgren et al. 2001, 2006b, Gutierrez et al. 2007, Squeo et al. 2007); lessons from those ecosystems showed the crucial importance of El Niño years as the appropriate "windows of opportunity" to overcome herbivory contraints and therefore allow forest recovery (Holmgren et al. 2006a).
We conceived the regeneration niche of Nothofagus species as intermediate between $A$. chilensis and $C$. alba shade and drought tolerance, thus we expected that they would have an intermediate response to forest fragmentation. Although this expectation was partially correct (i.e. N. obliqua germination did not vary between habitats), these species differed in their responses to forest fragmentation, suggesting differences in their light and drought stress tolerances. However, both species had low germination in the Coastal Maulino Forest (Table 3) (Burgos et al. 2008), this certainly contributed to the extremely low regeneration observed for these species (Bustamante et al. 2005, Burgos et al. 2008). Also, elevated pre-disperal predation also may contribute to the scarce regeneration observed in the field (Burgos et al. 2008). Finally, the masting property of Nothofagus species implies profuse seed production in some years and thus regeneration events may be linked to these episodes (Burgos et al. 2008). The occurrence of El Niño is thought to be associated with masting episodes in Nothofagus spp. in New Zealand (Schauber et al. 2002); to what extent this assertion holds and its implications for Chilean Nothofagus regeneration requires further research.

The forest fragmentation process in the Coastal Maulino Forest has many complex consequences on biological dynamics by modifying abiotic conditions (Henriquez 2002, and this study), species interactions (i.e. frugivory, granivory, herbivory and pollination) (Donoso et al. 2003, Valdivia et al. 2006, Simonetti et al. 2007, Valdivia \& Simonetti 2007), species abundances (Acosta-Jamett \& Simonetti 2004, Bustamante et al. 2005, and this study), and habitat invasiveness (Bustamante et al. 2003, Bustamante \& Simonetti 2005). All of these immediate consequences represent a great challenge to conservation practice and ecological restoration of the Coastal Maulino Forest. In spite of a drought intolerant species (i.e. C. alba) which diminished its regeneration in small forest remnants, this study shows that some species with a drought tolerant niche (i.e. A. chilensis and $N$. glauca) can successfully regenerate. The potential for forest recovery in small forest fragments may be facilitated because in this habitat the seedling herbivory is reduced 
(Simonetti et al. 2007, Vásquez et al. 2007), indicating that the abiotic constraints for seedlings are less restrictive than the observed scenario in Chilean arid and semi arid forests (Holmgren et al. 2006ab). To take advantage of this "window of opportunity" in the recovery of the Coastal Maulino Forest, we considered that conservation efforts to preserve small forest remnants and to integrating the $P$. radiata matrix in the conservation action are crucial (Guerrero \& Bustamante 2007). Moreover, this study highlights the relevance of studying changes in abiotic factors as a consequence of human activities, and considering safe sites (defined by regeneration niche attributes) for implementing conservation actions and ecological restoration.

\section{ACKNOWLEDGEMENTS}

We thank CONAF VII Region and Forestal Terranova S.A. for the necessary permission to access our study sites. Dirección Meteorológica de Chile for providing precipitation information. We also thank J. J. Armesto, L. A. Cavieres, J. Cuevas, J. A. Simonetti and three anonymous reviewers for their valuable comments that helped to improve this manuscript. In addition, we thank J. L. Celis-Diez, F. Campos, D. Donoso, P. Palacios, R. Zuñiga and Y. Zuñiga for field assistance. PCG acknowledges the support of the CONICYT doctoral fellowship D21070301. ROB acknowledges partial support of the project ICM - P05 - 002, the BBVA award in Conservation Biology 2004 and to ACT34/2006. This research was financed by a Fondecyt grant 1010852 .

\section{LITERATURE CITED}

ACOSTA-JAMETT G \& JA SIMONETTI (2004) Habitat use by Oncifelis guigna and Pseudalopex culpaeus in a fragmented forest landscape in central Chile. Biodiversity and Conservation 13: 1135-1151.

ARMESTO JJ \& JA MARTÍNEZ (1978) Relations between vegetation structure and slope aspect in the Mediterranean region of Chile. Journal of Ecology 66: 881-889.

BASKIN C \& J BASKIN (1998) Seeds: Ecology, biogeography and evolution of dormancy and germination. Academic Press, San Diego, California, USA. 666 pp.

BENITEZ-MALVIDO J (1998) Impact of forest fragmentation on seedling abundance in a tropical rain forest. Conservation Biology 12: 380-389.

BENITEZ-MALVIDO J \& M MARTÍNEZ-RAMOS (2003) Impact of forest fragmentation on understorey plant species richness in Amazonia. Conservation Biology 17: 389-400

BENDER EA, TJ CASE \& ME GILPIN (1984) Perturbation experiments in community ecology theory and practice. Ecology 65: 1-13.

BLOOR J \& PJ GRUBB (2003) Growth and mortality in high and low light: trends among 15 shade-tolerant tropical rain forest tree species. Journal of Ecology 91: 77-85.

BROOKS TM, RA MITTERMEIER, GAB DA FONSECA J GERLACH, H HOFFMANN et al. (2006) Global biodiversity conservation priorities. Science 313: 58-61.

BRUNA EM (1999) Seed germination in rain forest fragments. Nature 402: 139.

BRUNA EM (2002) Effects of forest fragmentation on Heliconia acuminata seedling establishment in central Amazonia. Oecologia 132: 235-243.

BRUNA EM (2003) Are plant population in fragmented habitats establishment limited? Tests with an Amazonian herb. Ecology 84: 932-947.

BUNNELL FL \& DJ VALES (1990) Comparison of methods for estimating forest overstory cover differences among techniques. Canadian Journal of Forestry Research 20: 101-107.

BURGOS A, AA GREZ \& RO BUSTAMANTE (2008) Seed production, pre-dispersal seed predation and germination of Nothofagus glauca (Nothofagaceae) in a temperate fragmented forest in Chile. Forest Ecology and Management 255: 1226-1233.

BUSTAMANTE RO (in press) Conectando la calidad de los dispersores de semillas con la demografía de las plantas: patrones y procesos poblacionales de Cryptocarya alba (Lauraceae) en el matorral de Chile central. In: Medel R, MA Aizen \& R Zamora (eds) Interacciones planta-animal y biodiversidad: conceptos y aplicaciones. Editorial Universitaria, Santiago, Chile.

BUSTAMANTE RO \& C CASTOR (1998) The decline of an endangered temperate ecosystem: The ruil (Nothofagus alessandrii) forest in central Chile. Biodiversity and Conservation 7: 1607-1626.

BUSTAMANTE RO \& JA SIMONETTI (2000) Seed predation and seedling recruitment in plants: the effect of the distance between parents. Plant Ecology 147: 173-183.

BUSTAMANTE RO \& JA SIMONETTI (2005) Is Pinus radiata invading the native vegetation in Central Chile? Demographic responses in a fragmented forest. Biological Invasions 7: 243-249.

BUSTAMANTE RO, I SEREY \& STA PICKETT (2003) Forest fragmentation, plant regeneration and invasion processes in Central Chile. In: Bradshaw G, P Marquet \& M Mooney (eds) How landscapes change: Human disturbance and ecosystem fragmentation in the Americas: 145-160. SpringerVerlag, New York, USA.

BUSTAMANTE RO, JA SIMONETTI, AA GREZ \& J SAN MARTIN (2005) La fragmentación del bosque Maulino y su dinámica regeneracional: diagnóstico actual y perspectivas futuras. In: Smith-Ramírez C, JJ Armesto \& C Valdovinos (eds) Historia, biodiversidad y ecología de los bosques costeros de Chile: 555-564. Editorial Universitaria, Santiago, Chile.

CELIS-DIEZ JL, RO BUSTAMANTE \& RA VÁSQUEZ (2004) Assessing frequency dependent seed size 
selection: A field experiment. Biological Journal of the Linnean Society 81: 307-312.

CHEN J, JF FRANKLIN \& TA SPIES (1992) Vegetation responses to edge environments in old-growth Douglas-fir forests. Ecological Applications 2: 387396.

DENSLOW JS (1987) Tropical rainforest gaps and tree species diversity. Annual Review of Ecology and Systematics 18: 431-451.

DONOSO C (1975) Aspectos de la fenología y germinación de las especies de Nothofagus de la zona mesomórfica. Boletín técnico $\mathrm{n}^{\circ} 34$. Universidad de Chile, Facultad de Ciencias Forestales, Departamento de Silvicultura, Chile. 32 pp.

DONOSO C (1997) Ecología forestal, el bosque y su medio ambiente. Quinta edición. Editorial Universitaria, Santiago, Chile. 485 pp.

DONOSO DS, AA GREZ \& JA SIMONETTI (2003) Effects of forest fragmentation on the granivory of differently sized seeds. Biological Conservation 115: 63-70.

DUNSON WA \& J TRAVIS (1991) The role of abiotic factors in community organization. The American Naturalist 138: 1067-1091.

ECHEVERRÍA C, D COOMES, J SALAS, JM REYBENAYAS, A LARA \& A NEWTON (2006) Rapid deforestation and fragmentation of Chilean Temperate Forests. Biological Conservation 130: 481-494.

ESTADES CF \& SA TEMPLE (1999) Temperate-forest bird communities in a fragmented landscape dominated by exotic pine plantations. Ecological Applications 9: 573-585.

FUENTES ER, A HOFFMANN, A POIANI \& C ALLIENDE (1986) Vegetation change in large clearings: patterns in Chilean matorral. Oecologia 68: 358-366.

FUENTES ER, R OTAIZA, C ALLIENDE, A HOFFMANN \& A POIANI (1984) Shrub clumps of the Chilean matorral vegetation: structure and possible maintenance mechanisms. Oecologia 62: 405-411.

GRUBB PJ (1977) The maintenance of species-richness in plant communities: the importance of the regeneration niche. Biological Review 52: 107-145.

GRUBB PJ, WG LEE, J KOLLMANN \& JB WILSON (1996) Interaction of irradiance and soil nutrient supply on growth of seedlings of ten European tallshrub species and Fagus sylvatica. Journal of Ecology 84: 827-840.

GUERRERO PC \& RO BUSTAMANTE (2007) Can native tree species regenerate in Pinus radiata plantations in Chile? Evidence from field and laboratory experiments. Forest Ecology and Management 253: 97-102.

GUTIERREZ JR, M HOLMGREN, R MANRIQUE \& FA SQUEO (2007) Reduced herbivore pressure under rainy ENSO conditions could facilitate dryland reforestation. Journal of Arid Environments 68: $322-330$

HARPER J (1977) Population biology of plants. Academic Press. London, UK. 892 pp.

HENRÍQUEZ CA (2002) El dilema de Lapageria rosea en bosques fragmentados: ¿cantidad o calidad de la progenie? Doctoral Thesis, Universidad de Chile, Santiago, Chile. 133 pp

HOFFMANN AE (1998) Flora silvestre de Chile: zona central. Ediciones Fundación Claudio Gay, Santiago, Chile. 254 pp.
HOLMGREN M, M SCHEFFER, E EZCURRA, JR GUTIÉRREZ \& F MOHREN (2001) El Niño effects on the dynamics of terrestrial ecosystems. Trends in Ecology and Evolution 16: 89-94.

HOLMGREN M, BC LÓPEZ, JR GUTIÉRREZ \& FA SQUEO (2006a) Herbivory and plant growth rate determine the success of El Niño Southern Oscillation-driven tree establishment in semiarid South America. Global Change Biology 12: 22632271.

HOLMGREN M, P STAPP, CR DICKMAN, C GRACIA, S GRAHAM et al. (2006b) Extreme climatic events shape arid and semiarid ecosystems. Frontiers in Ecology and the Environment 4: 87-95.

JENNINGS SB, ND BROWN \& D SHEIL (1999) Assessing forest canopies and understorey illumination: canopy closure, canopy cover and other measures. Forestry 72: 59-73.

KAPOS V (1989) Effects of isolation on the water status of forest patches in the Brazilian Amazon. Journal of Tropical Ecology 5: 173-185.

KAPOS V, E WANDELLI, JL CAMARGO \& G GANADE (1997) Edge-related changes in environment and plant responses due to forest fragmentation in central Amazonia Tropical forest remnants. In: Laurance WF \& RO Bierregard (eds) Ecology, management, and conservation of fragmented communities: 33-44. University of Chicago Press, Chicago, USA.

KITAJIMA K \& M FENNER (2000) Ecology of seedling regeneration. In: Fenner $M$ (ed.) Seed: the ecology of regeneration in plant communities: 331-359. Second Edition. CAB International, Wallingford.

LAURANCE WF, LV FERREIRA, JM RANKIN-DE MERONA, SG LAURANCE, RW HUTCHINGS \& TE LOVEJOY (1998) Effects of forest fragmentation on recruitment patterns in Amazonian tree communities. Conservation Biology 12: 460-464.

LUEBERT F \& P PLISCOFF (2006) Sinopsis bioclimática y vegetacional de Chile. Editorial Universitaria, Santiago, Chile. 316 pp.

MARKESTEIJN L \& L POORTER (2009) Seedling root morphology and biomass allocation of 62 tropical tree species in relation to drought and shadetolerance. Journal of Ecology 97: 311-325.

MONTECINOS A \& P ACEITUNO (2003) Seasonality of the ENSO-related rainfall variability in Central Chile and associated circulation anomalies. Journal of Climate 16: 281-296.

PALACIOS-BIANCHI PA (2002) Producción y descomposición de hojarasca en un bosque Maulino fragmentado. Undergraduate Thesis, Facultad de Ciencias, Universidad Chile, Santiago, Chile. 19 pp.

RESTREPO C \& A VARGAS (1999) Seeds and seedlings of two neotropical montane vegetation shrubs respond differently to anthropogenic edges and treefall gaps. Oecologia 119: 419-426.

RODRÍGUEZ R, O MATTHEI \& M QUEZADA (1983) Flora arbórea de Chile. Editorial de la Universidad de Concepción, Concepción, Chile. 408 pp.

SAAVEDRA B \& JA SIMONETTI (2001) New records of Dromiciops gliroides (Microbiotheria: Microbiotheriidae) and Geoxus valdivianus (Rodentia: Muridae) in central Chile: Their implications for biogeography and conservation. Mammalia 65: 96-100.

SAN MARTÍN J \& C DONOSO (1996) Estructura florística e impacto antrópico en el bosque Maulino de Chile. In: Armesto JJ, C Villagrán \& MTK 
Arroyo (eds) Ecología de los bosques nativos de Chile: 153-168. Editorial Universitaria, Santiago, Chile.

SCHAUBER EM, D KELLY, P TURCHIN, C SIMON, WG LEE et al. (2002) Masting by eighteen New Zealand plant species: The role of temperature as a synchronizing cue. Ecology 83: 1214-1225.

SIMONETTI JA, AA GREZ, JL CELIS-DIEZ \& RO BUSTAMANTE (2007) Herbivory and seedling performance in temperate forest of Chile. Acta Oecologica 32: 312-318

SIZER N \& EVJ TANNER (1999) Responses of woody plant seedlings to edge formation in a lowland tropical rainforest, Amazonia. Biological Conservation 91: 135-142.

SMITH-RAMÍREZ C (2004) The Chilean coastal range: a vanishing center of biodiversity and endemism in South American temperate rainforests. Biodiversity and Conservation 13: 373-393.

SMITH T \& M HUSTON (1989) A theory of the spatial and temporal dynamics of plant communities. Vegetatio 83: 49-69.

SQUEO FA, M HOLMGREN, M JIMÉNEZ, J ALBÁN L, REYES \& JR GUTIÉRREZ (2007) Tree establishment along an ENSO experimental gradient in the Atacama desert. Journal of Vegetation Science 18: 193-200.

VALDIVIA CE, JA SIMONETTI \& CA HENRÍQUEZ (2006) Depressed pollination of Lapageria rosea
Ruiz et Pav. (Philesiaceae) in the fragmented temperate rainforest of southern South America. Biodiversity and Conservation 15: 1845-1856.

VALDIVIA CE \& JA SIMONETTI (2007) Decreased frugivory and seed germination rate do not reduce seedling recruitment rates of Aristotelia chilensis in a fragmented forest. Biodiversity and Conservation 16: $1593-1602$

VALLADARES F \& U NIINEMETS (2008) Shade tolerance, a key plant feature of complex nature and consequences. Annual Review of Ecology, Evolution, and Systematics 39: 237-257.

VÁSQUEZ PA, AA GREZ, RO BUSTAMANTE \& JA SIMONETTI (2007) Herbivory, survival and shoot growth in fragmented populations of Aristotelia chilensis. Acta Oecologica 31: 48-53

VELOSO A, JL CELIS-DIEZ, PC GUERRERO, MA MÉNDEZ, P ITURRA \& JA SIMONETTI (2005) Description of a new Eupsophus species (Amphibia, Leptodactylidae) from the remnants of Maulino forest, central Chile. Herpetological Journal 15: 159-165.

VILLAGRÁN C \& LF HINOJOSA (1997) Historia de los bosques del sur de Sudamérica, II: análisis fitogeográfico. Revista Chilena de Historia Natural 70: 241-267.

ZAR JH (1999) Biostatistical analysis. Third Edition. Prentice-Hall International, Englewood Cliffs, New Jersey, USA. 663 pp. 